\title{
Performance and emission characteristics of waste cooking oil as biodiesel in CI Engine
}

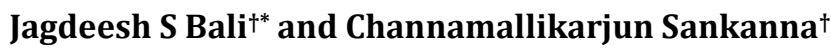 \\ †Department of Mechanical Engineering, Savitribai Phule Pune University, PGMCOEW Agholi, Pune India
}

Accepted 03 March 2016, Available online 15 March 2016, Special Issue-4 (March 2016)

\begin{abstract}
The petroleum products are very shortage, and these are depleting day by day in use. In this regards an alternatives fuel plays a very important rule. The biodiesel is one of the alternative fuels which can be produced from vegetable oils (edible or non edible oil), animal fats and Waste cooking oil. In these lessons, the biodiesel is produced from waste cooking oil by a method of transisterification, after this, the biodiesel is blended with diesel in proportion of $20 \%$, $40 \%, 60 \%$, and 80\%, on quantity basis along with pure biodiesel, are analyzed and compare with diesel. The present work has mainly on the performance and emission characteristics of waste cooking oil and its blend with diesel, at variable loads (brake power) of 0, 1, 2, 3, 4 and $5.2 \mathrm{~kW}$ at constant rated speed of $1500 \mathrm{rpm}$. The experimental results show that the lower blends of biodiesel there is a raise in brake thermal efficiency, mechanical efficiency; volumetric efficiency and BSFC are well comparable with diesel. And there is reduce of $\mathrm{CO}, \mathrm{CO}_{2}$, and $\mathrm{HC}$ as compare with diesel. Hence it is seen that the use of biodiesel produced from waste cooking oil can be an alternative fuel in a diesel engine. And also up to B20 there is no modification needed to the engine.
\end{abstract}

Keywords: Trasisterification process, Engine performance, Exhaust emissions, Fossil fuel, Biodiesel, alternative fuels.

\section{Introduction}

Vegetable oil is used commonly in cooking and is needed particularly to fry food. After using the same oil over and over again, the remaining oil becomes spoiled with old food remains and can no longer be used for cooking the food. If this waste used cooking oil is disposed into a surrounding which can be a big problem Rickeard et al. Instead of disposing we can use this waste cooking oil in diesel engines as a fuel if it is cleaned and properly converted to combustible diesel oil Demirbas et al. If a large amount of waste cooking oil is used in the Diesel engine, it can reduce the large amount of using petroleum fuel Nwafor et al. The used cooking oil is fundamentally a waste product and for that reason it is cheaper than unused (virgin) vegetable oil. The some of the vegetable oil or Cooking oils are used for frying are sunflower oil, palm oil, coconut oil etc. these are easily available India Rakopoulos et al. The waste cooking oil samples used for the purpose is of usually palm oil because it is usually used oil in the restaurants and hostel kitchens. The waste cooking oil is generated from the Fraying of food with high temperatures are generated due to this changes in its chemical and physical composition, as well as in its organic properties which affect both the food and oil quality. Used cooking oil is normally black, a strong odor Dorado et al.
Environmental problems for disposing waste cooking oil Pugazhvadivu et al.

1) When this waste cooking oil is dumped into river or any water source which can react with water and increases organic pollution in the water, and which alters the ecosystem.

2) This waste cooking oil is causes problem in the pipes drain obstructing them and creating odors and increasing the cost of wastewater treatment.

3) The hazardous odors create a negative impact on health, mainly by hydrogen sulfide $\left(\mathrm{H}_{2} \mathrm{~S}\right)$, which can cause irritation of the respiratory tract, skin problem, headaches and eye irritation

Table 1: Chemical composition of waste cooking oil

\begin{tabular}{|c|c|}
\hline Features & $\begin{array}{c}\text { Oil collected by the hotel } \\
\text { sector }\end{array}$ \\
\hline Acidity (\%) & 0.56 \\
\hline Moisture & 0.25 \\
\hline Viscosity at $37^{\circ} \mathrm{C}\left(\mathrm{mm}^{2} / \mathrm{s}\right)$ & 44.78 \\
\hline Iodine index $\left(\mathrm{Cgl}_{2} / \mathrm{g}\right)$ & 108.22 \\
\hline $\begin{array}{c}\text { Un saponifiable material } \\
(\%)\end{array}$ & 1.70 \\
\hline $\begin{array}{c}\text { Saponification index (mg } \\
\mathrm{KOH} / \mathrm{g})\end{array}$ & 195.87 \\
\hline Ash (\%) & 0.030 \\
\hline Refractive index $25^{\circ} \mathrm{C}$ & 1.4700 \\
\hline Density $15^{\circ} \mathrm{C}\left(\mathrm{kg} / \mathrm{m}^{3}\right)$ & 910 \\
\hline
\end{tabular}




\section{Methods for making biodiesel}

The waste cooking oil (WCO) has properties different from the properties of refined / crude fresh cooking oils. During frying process there is a presence of heat and water which accelerates the hydrolysis of triglycerides and increases content of free fatty acids in oil. The Oxidation stability of the oil is disturbed because of the contact of hot oil with food, and peroxide value of oil increases Huzayyin et al. Viscosity of oil increases significantly, because of the formation of dimeric and polymeric acids and glycerides. Also density increases, due to its high viscosity, this oil get chemically modified into esters whose properties resemble those of fossil fuels. These chemically modified processes are called transisterification Jothi et al.. This process requires heat and a strong catalyst (alkalis, acids, or enzymes) to achieve complete conversion of the vegetable oil into the separated esters and glycerin Agarwal et al. During the transisterification reaction, glycerin is obtained as a by-product.

\subsection{Transisterification procedures}

It consists of four steps as follows:

1) Add the catalyst to neutralize the free fatty acids

2) Preparation of methoxide solution

3) Formation of biodiesel and glycerol

4) Clean the obtained bio-diesel

STEP: $1:$ In this step, find out the amount of catalyst required to neutralize the free fatty acids. This can be done by titration process.

The following are required for doing the titration process: $1 \mathrm{ml}$ of oil, 1 litre of distilled water, $10 \mathrm{ml}$ isopropyle alcohol, $1 \mathrm{gm}$ of catalyst, 2 drops of color indicator (phenapthelene).

First prepare the stock solution by adding $1 \mathrm{gm}$ of $\mathrm{KOH}$ in a perfect measured one liter of distilled water. Then this value becomes $1 \mathrm{gm} / 1000 \mathrm{ml}$ or 0.001 alkali. Fill the stock solution in $25 \mathrm{ml}$ burette. Then take $1 \mathrm{ml}$ of oil using pipette and dilute this in $10 \mathrm{ml}$ of iso propyl alcohol. Add two drops of phenapthelene colour indicator and keep it closed. Then start the titration process. Then the colour of the oil changes into pink colour. Then watch the burette how much $\mathrm{ml}$ is consumed. If suppose it is consumed by $5 \mathrm{ml}$, then there is a $5 \%$ of free fatty acids and we require $20 \mathrm{gm}$ of catalyst to neutralize fatty acids. In this our oil has $1 \%$ of FFA. Thus it requires $5 \mathrm{gm}$ of $\mathrm{KOH}$ with $200 \mathrm{ml}$ of methanol.

STEP: 2:Prepare the methoxide solution by mixing of methanol with potassium hydroxide. Mix the $5 \mathrm{gm}$ of $\mathrm{KOH}$ with $200 \mathrm{ml}$ of methanol and keep it safely.

STEP: 3:Take the one liter of oil, heat the oil up to $65^{\circ} \mathrm{C}$ and react with methoxide solution fastly by using a glass rod. Then pour the oil in a separate vessel and allow sufficient time for separation of bio-diesel and glycerol.After some time, we find two layers which are maximum at top and minimum at bottom. The top layer is called bio-diesel or methyl ester and the bottom layer is a byproduct called glycerol.

STEP 4: Clean the oil with the distilled water for two or three times. First clean the oil with distilled water to remove the untreated methoxide and then heat the oil to remove any water traces and finally we obtain a clear bio-diesel.The following are the proportions for transisterification process of waste cooking oil with no free fatty acids.

Table 2: chemical proportion of WCO

\begin{tabular}{|c|c|c|}
\hline S .No & Chemical & Proportion \\
\hline 1. & Waste cooking oil & $1000 \mathrm{ml}$ \\
\hline 2. & Catalyst- KOH & $5 \mathrm{gm}$ \\
\hline 3. & Methanol & $200 \mathrm{ml}$ \\
\hline
\end{tabular}

\subsection{Biodiesel blend preparation}

The tests were carried out with B20 (20\% bidoiesel$80 \%$ diesel by volume),B40 ( $40 \%$ biodiesel- $60 \%$ diesel by volume), B60 (60\%biodiesel $-40 \%$ diesel volume), B80 (80\% bidoiesel-20\% diesel by volume) and B100 (net biodiesel).Blends were prepared on a volume basis at $25^{\circ} \mathrm{C}$.

Table 3: density and calorific value of different fuel blends

\begin{tabular}{|c|c|c|c|}
\hline Sl. No & $\begin{array}{c}\text { Blend of } \\
\text { fuel }\end{array}$ & $\begin{array}{c}\text { Density } \\
\left(\mathrm{Kg} / \mathrm{m}^{3}\right)\end{array}$ & $\begin{array}{c}\text { Calorific } \\
\text { value }(\mathrm{KJ} / \mathrm{Kg})\end{array}$ \\
\hline 1 & $\mathrm{~B} 0$ & 840 & 42500 \\
\hline 2 & $\mathrm{~B} 20$ & 850 & 40750 \\
\hline 3 & $\mathrm{~B} 40$ & 860 & 39100 \\
\hline 4 & $\mathrm{~B} 60$ & 870 & 37200 \\
\hline 5 & $\mathrm{~B} 80$ & 882 & 36640 \\
\hline 6 & $\mathrm{~B} 100$ & 892 & 35640 \\
\hline
\end{tabular}

Table 4: Properties of standard diesel and biodiesel

\begin{tabular}{|c|c|c|c|}
\hline Property & WCO & Biodiesel & Diesel \\
\hline $\begin{array}{c}\text { Kinematic Viscosity } \\
\text { At } 40^{\circ} \mathrm{C}\left(\mathrm{mm}^{2} / \mathrm{s}\right)\end{array}$ & 39.7 & 6.58 & 2.4 \\
\hline Calorific Value $(\mathrm{M} / \mathrm{kg})$ & 34.23 & 35.64 & 42.5 \\
\hline Cloud Point $\left({ }^{\circ} \mathrm{C}\right)$ & 0 & 2 & -5 \\
\hline Pour Point $\left({ }^{\circ} \mathrm{C}\right)$ & -40.7 & -8 & -20 \\
\hline Flash Point $\left({ }^{\circ} \mathrm{C}\right)$ & 278 & 180 & 75 \\
\hline $\begin{array}{c}\text { Density } \\
\left(\mathrm{kg} / \mathrm{m}^{3} \text { ) At } 15{ }^{\circ} \mathrm{C}\right.\end{array}$ & 910 & 892 & 840 \\
\hline
\end{tabular}

\section{Experimental Work}

Table 5: Specifications of the engine

\begin{tabular}{|c|}
\hline $\begin{array}{c}\text { Name of the engine: AV1 Kirloskar Oil } \\
\text { Engines Ltd India }\end{array}$ \\
\hline Model :TV SR II naturally aspirated \\
\hline Engine : single cylinder, DI \\
\hline Number of cylinders : 1 \\
\hline Bore: $87.5 \mathrm{~mm}$ \\
\hline Stroke $: 110 \mathrm{~mm}$ \\
\hline
\end{tabular}




\begin{tabular}{|c|}
\hline Rated power: $5.2 \mathrm{~kW}$ \\
\hline Working cycle : four stroke \\
\hline Injection pressure $: 185$ bar \\
\hline Injection timing $: 23$ deg TDC \\
\hline Type of sensor : piezo electric \\
\hline Rated speed $: 1500 \mathrm{rpm}$ constant \\
\hline Compression ratio $: 16.5: 1$ \\
\hline
\end{tabular}

\subsection{Experimental technique}

This computerized test rig was used for recording the test parameters such as fuel flow rate, temperatures, air flow rate, load etc. and for calculating the engine performance characteristics such as brake thermal efficiency, brakes specific fuel consumption, Volumetric efficiency etc., the calorific value and the density of a particular fuel was fed to the software as input variables. Planet Equipment of gas analyzer isused to find out the emission character's on carbon monoxide (CO), carbon dioxide $\left(\mathrm{CO}_{2}\right)$, un-burnt hydro carbon.

\subsection{Experimental procedure}

The engine was run at a variable load (BP) of $0,1,2,3$, 4 and $5 \mathrm{~kW}$ at a constant rated speed of 1500rpm with fuel injector pressure of 185 bar cooling water exit temperature of $62^{\circ} \mathrm{C}$. The engine was sufficiently warmed up and stabilized before taking all readings. Different blends of biodiesel from waste cooking oil with diesel were prepared namely B20, B40, B60,B80 and B100. Before using blend, each one was mixed thoroughly. Then in the similar manner as in case of diesel fuel reading of each meter is noted down. During each blend, the filter of diesel engine was opened and complete mixture of biodiesel and diesel was drained so that it could not impure next blend by mixing with its previous blend. Then again for another blend, in the similar fashion, the experiment was repeated for knowing the above stated parameters. The performance characteristic of the engine is evaluated in terms of brake thermal efficiency, brake specific fuel consumption, and emission characteristics in terms of smoke, unborn $\mathrm{HC}, \mathrm{CO}$ and exhaust temperature. These performance and emission characteristics are compared with the results of baseline diesel.

\section{Result and Discussions}

Fuel consumption $(\mathrm{kg} / \mathrm{h})$ :The Figure shows variations of fuel consumption with brake power for different blends with diesel. It shows the fuel consumption increases corresponding to increase of brake power. The fuel consumption depends up on the calorific value of the fuels. With increase in the calorific value the fuel consumption reduces. The diesel fuel has more calorific value compared with the fuel blends. So the fuel consumption of the blends are higher than the diesel fuel due to lower calorific value of the fuel blends (B20,B40, B60 B80 and B100),the fuel consumption for diesel is $33.5(\mathrm{~kg} / \mathrm{h})$, whereas $B 20$ is $34.7(\mathrm{~kg} / \mathrm{h})$, is higher by $1.2(\mathrm{~kg} / \mathrm{h})$ and we can say that fuel consumption of B20 is well comparable. For B40, $\mathrm{B} 60$ and B80, corresponding fuel consumption is 39.05 , 49.6, and $52.6(\mathrm{~kg} / \mathrm{h})$.

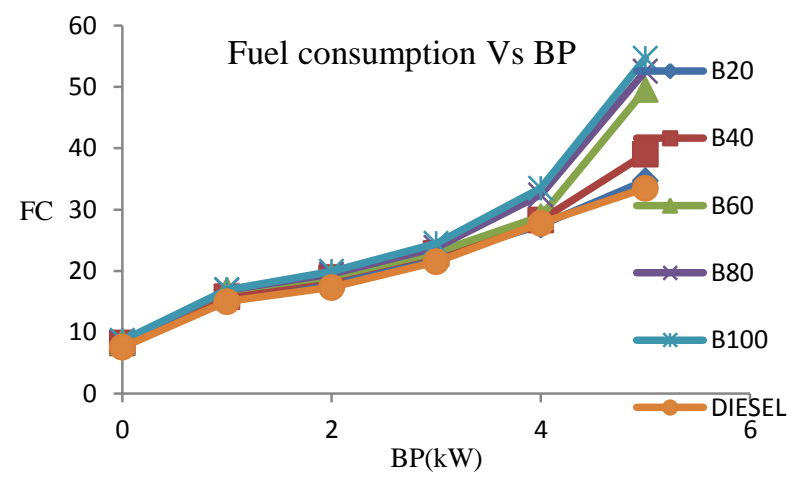

Figure 1: Fuel consumption Vs BP for different blends

Specific fuel consumption (kg/kW-h): The Figure shows the variations of the specific fuel consumption with brake power for different blends, with diesel. It shows the specific fuel consumptions are reduced with increase in the brake power. The specific fuel consumption of the Bio diesel blends are more than the diesel fuel. The specific fuel consumption depends upon the friction, high speed and the heat release rate. The fuel blends (B20, B40, B60, B80 and B100) have lower heat release rates. So the specific fuel consumption is higher than the diesel fuel. The SFC of $\mathrm{B} 20$ is $0.465(\mathrm{~kg} / \mathrm{kW}-\mathrm{h})$ against diesel is $0.438(\mathrm{~kg} / \mathrm{kW}$ $\mathrm{h}$ ) is higher by $0.027(\mathrm{~kg} / \mathrm{kW}-\mathrm{h})$. We can say that fuel consumption of B20 is well comparable.

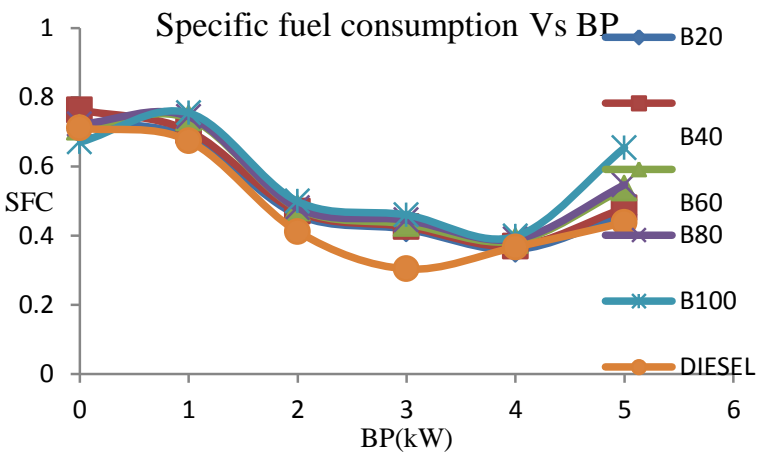

Figure 2: Variations of BP with specific fuel consumption for different blends

Brake thermal efficiency (\%):The Figure shows the variations of BP with specific fuel consumption for WCO blends with diesel. The brake thermal efficiency for B20 and B40 was comparable to efficiency of diesel fuel. It indicates that higher cetane number and inherent presence of oxygen in the biodiesel produced better combustion. The maximum brake thermal efficiency of B20 BTE is $20.4 \%$ which is almost near to diesel, so we can say that B20 is comparable with diesel fuel. 


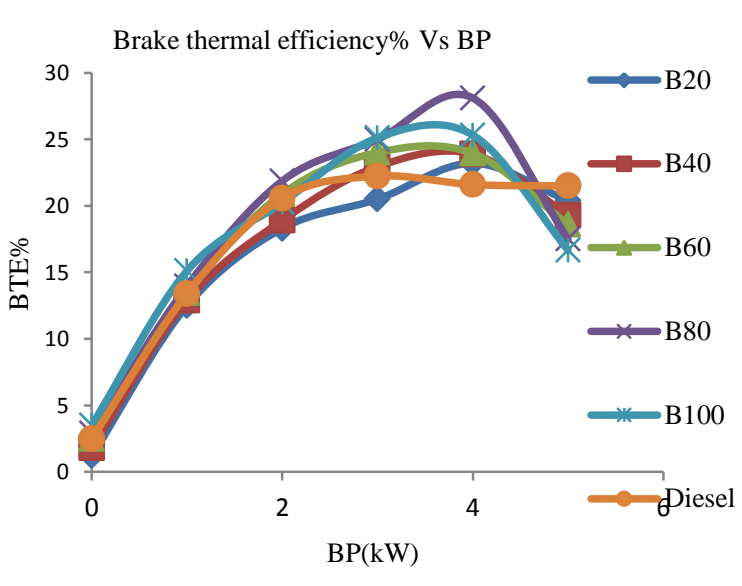

Figure 3: Variations of BP with Brake thermal efficiency for different blends

Mechanical efficiency (\%):The Figure shows the Variation of mechanical efficiency with brake power for different WCO blends with diesel oil. The mechanical efficiency for B20 is similar to diesel oil. And at low load B80 and B60 are of mechanical efficiency higher than that of diesel oil. This is because of low viscosity, higher cetane number and inherent presence of oxygen in the biodiesel produced better combustion. The maximum mechanical efficiency for diesel oil is $62.71 \%$ and maximum mechanical efficiency for B20 is $61.35 \%$.

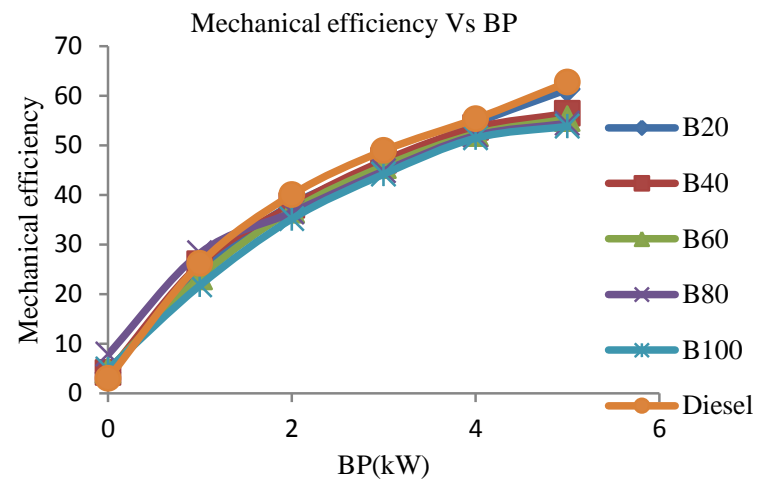

Figure 4: Variations of BP with mechanical efficiency for different blends

Volumetric efficiency (\%): The Volumetric efficiency decreases with increase in concentration of waste cooking oil in diesel. The increase in exhaust gas temperature may be responsible for reduction in volumetric efficiency. The maximum volumetric efficiency for diesel oil is $100 \%$ is $85.4 \%$ but it is reduced by adding waste cooking oil in diesel oil. The volumetric efficiency for B20, B40, B60, B80 and $\mathrm{B} 100 \%$ are 76.8, 74.9, 74.4, 73.7 and $71.38 \%$ respectively.

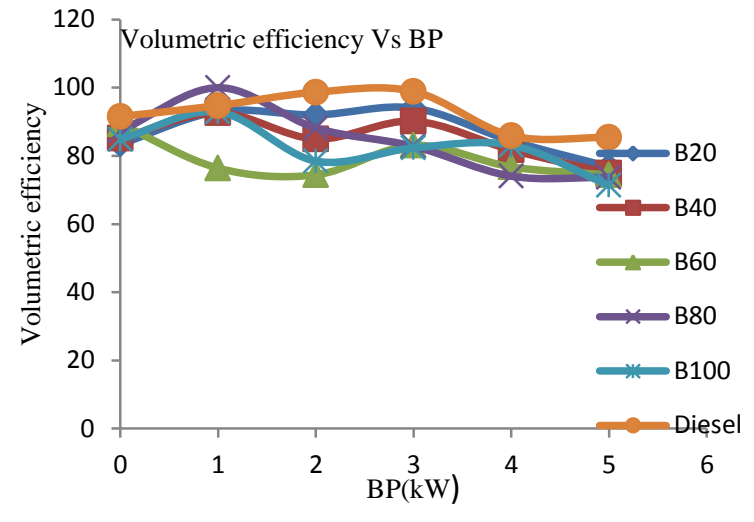

Figure 5: Variations of BP with volumetric efficiency for different blends

Carbon dioxides $\left(\mathrm{CO}_{2}\right)$ :The variations of carbon dioxide with brake power for different blends with Diesel as shown in figure.The addition of the biodiesel to the blend decreased the $\mathrm{CO}_{2}$ emissions. At full load condition the carbon dioxide emission of diesel fuel is higher than blended fuels. This may be because of the vegetable oil containing oxygen elements, increasing percentage of biodiesel in the blend, decrease the emission of $\mathrm{CO}_{2}$. For $\mathrm{B} 20$ and $\mathrm{B} 40$ biodiesel the emission is less than diesel at all load condition. There is reducing in $\mathrm{CO}_{2}$ because of higher cetane number in Biodiesel as compared standard diesel $\mathrm{CO}_{2}$ emission by improving combustion.

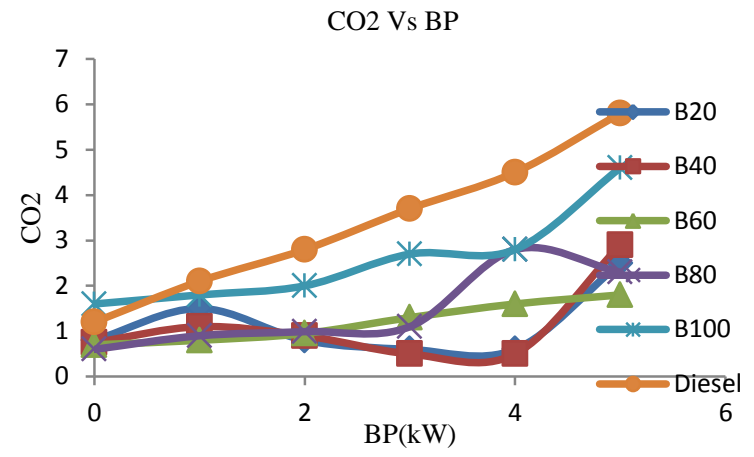

Figure 6: Variations of $\mathrm{BP}$ with $\mathrm{CO}_{2}$ for different blends

Carbon monaxide (CO): The variations of the carbon monoxide with brake power for different blends with Diesel are shown in Figure. It is experientially seen that the engine emits more $\mathrm{CO}$ fordiesel as compared to biodiesel blends under all loading conditions. In engine, CO formations are as a result of incomplete combustion due to mainly lack of oxidants. At the maximum load condition carbon monoxide emissions decrease for B20, B40, B60 and B80. The CO emission of B20 blends decreased more significantly at full load This may be due to the enrichment of oxygen in the waste cooking oil, in which an increase in the proportion of oxygen promotes further oxidation of $\mathrm{CO}$ during the engine exhaust process. At lower percent of waste cooking oil in diesel, leads to decrease the emission of $\mathrm{CO}$ due to the oxygen present in it, aids for 
complete combustion. However as the waste cooking oil concentration increases, the negative effect due to viscosity that shows the value in B100 (1.5PPM) and B80 (1.25).

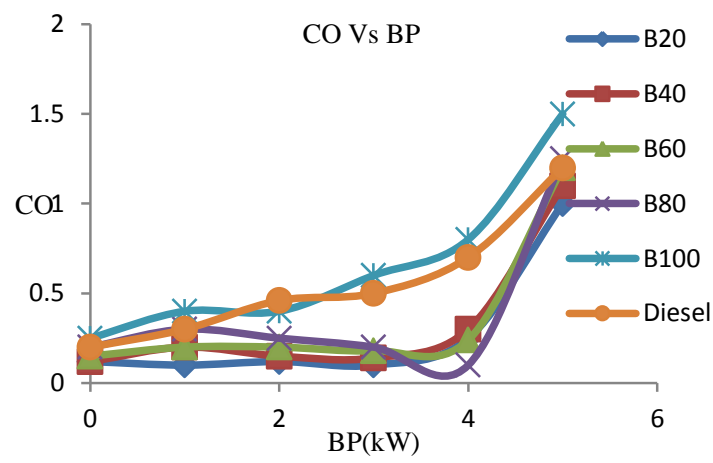

Figure 7: Variations of BP with CO for different blends

Hydro carbons (HC):The variations of hydrocarbon emission with brake power for different blends with Diesel are shown in Figure. The main reason for variations in HC Emission is due to the carbon and hydrogen content of the fuel. The $\mathrm{HC}$ emissions for blends are lower than diesel fuel, because biodiesel fuel having higher oxygen content in it due to this to complete combustion takes place in biodiesel. The fuel blends (B20, B40, B60, B80 and B100) have the lower carbon residue and hydrogen than the diesel fuel at all load conditions. The B20 has the lowest hydrocarbon emission than the other fuels. The maximum hydrocarbon emission for diesel fuel is 233ppm

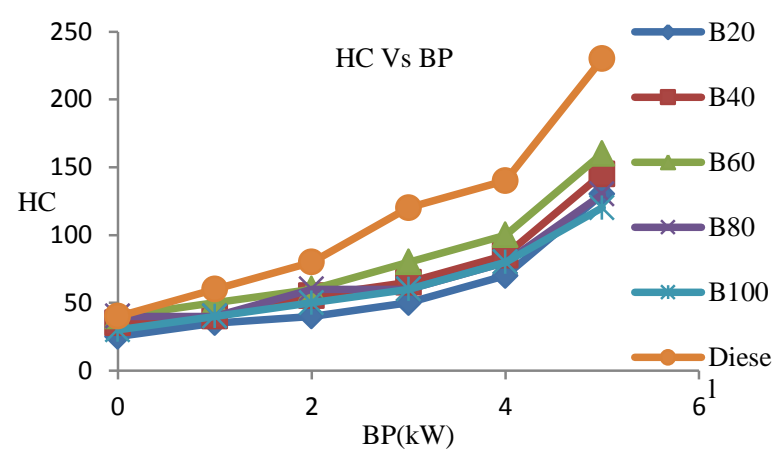

Figure 8: Variations of BP with HC for different blends

\section{Conclusions}

From the above Experiment, the following conclusions are drawn.

- The properties of density, viscosity, flash point, and fire point of waste cooking oil is higher and calorific values lower than diesel.

- The fuel consumption of the blends are higher than the diesel fuel due to lower calorific value of the fuel blends (B20,B40,B60 and B80).The fuel consumption for diesel is $33.5(\mathrm{~kg} / \mathrm{h})$, whereas $\mathrm{B} 20$ is $34.7(\mathrm{~kg} / \mathrm{h})$, is higher by $1.2(\mathrm{~kg} / \mathrm{h})$.

- The specific fuel consumption of the Biodiesel blends are more than the diesel fuel. The SFC of $\mathrm{B} 20$ is $0.465(\mathrm{~kg} / \mathrm{kW}-\mathrm{h})$ againstdiesel is $0.438(\mathrm{~kg} / \mathrm{kW}-\mathrm{h})$ is higher by $0.027(\mathrm{~kg} / \mathrm{kW}$ h).The brake thermal efficiency for biodiesel for all blends range was fond almost comparable to efficiency of diesel fuel.

- The maximum brake thermal efficiency of B100 is $28.9 \%$, against $21.5 \%$ of diesel oil which is higher by $7.4 \%$. B20 BTE is $23.9 \%$ which is almost near to diesel.

- The maximum mechanical efficiency for diesel oil is $62.71 \%$ and maximum mechanical efficiency for $100 \%$ blend is $65.92 \%$. The higher the concentration of blend with biodiesel the lower the engine performance.

- The biodiesel blends have the high exhaust gas temperature. Due to this volumetric efficiency of diesel fuel is more.

- The smoke densities of the fuel blends (B20, B40, $\mathrm{B} 60$ and B80) are higher than the diesel fuel.

- There was a reduction in CO emission for B20 blend at full load condition.

- The standard diesel produced the highest CO2 concentrations.

- The hydrocarbon emissions of the blends (B20, B40, B60 and B80) are lower than the diesel fuel at all load conditions. The maximum hydrocarbon emission for diesel fuel is $230 \mathrm{ppm}$.

So waste cooking oil used as Biodiesel in IC engine without any modification. And consider as alternative fuel for Diesel engine.

\section{References}

Rickeard, D. J. and Thompson, N. D. (1993) A review of the potential for biofuel as transportation fuels,SAE Technical Paper Series, SAE 932778.

Demirbas, A., 2006. Biodiesel production via non-catalytic SCF method and biodiesel fuel characteristics, Energy Conversion Management 47, pp. 2271- 2282.

Nwafor, O.M.I., 2004. Emission characteristics of diesel engine running on vegetable oil with elevated fuel inlet temperature, Biomass Bio energy 27, pp.507-511.

Rakopoulos, C.D., K.A., Antonopoulos, Rakopoulos D.C., D.T., Hountalas, and E.G., Giakoumis, 2006. Comparative performance and emissions study of a direct injection diesel engine using blends of diesel fuel with vegetable oils or biodiesels of various origins, Energy Conversion Management47, pp.3272- 3287

Dorado, M.P., E.A., Ballesteros, J.M., Arnal, J.,Gomez, and F.J., Lopez., 2003.Exhaustemissions from a diesel enginefueled with transisterified waste olive oil, Fuel 82, pp. 1311-1315.

Pugazhvadivu, M., K., Jeyachandran, 2005. Investigations on the performance exhaust emissions of a diesel engine using preheated waste frying oil as fuel, Renewable Energy 30, pp. 2189-2202.

Huzayyin, A.S., A.H., Bawady, M.A., Rady, and A., Dawood., 2004. Experimental evaluation of diesel engine performance and emission using blends of jojoba oil and diesel fuel, Energy Conversion Management 45, pp. 2093-2112.

Jothi, N.K.M., G., Nagarajan, and S., Renganarayanan, 2007. Experimental studies on homogeneous charge CI engine fueled with LPG using DEE as an ignition enhancer, Renewable Energy 32, pp.1581-1593

Dr. Avinash Kumar Agarwal (2008), Experiment to study the properties and the performance of non edible vegetable oils in a diesel engine Indian Institute of Technology Kanpur. 